\title{
Comparison of Drill- and Needle-based Tree Injection Technologies in Healing of Trunk Injection Ports on Apple Trees
}

Srđan G. Aćimović ${ }^{1, *}$, Bert M. Cregg ${ }^{2}$, George W. Sundin ${ }^{1}$ and John C. Wise ${ }^{3}$

${ }^{1}$ Michigan State University, Department of Plant, Soil and Microbial Sciences, 578 Wilson Road, East Lansing, Michigan 48824-1311, USA. Cell: 517449 0905; Phone: 517432 2668; fax. 517 353 5598; E-mail: acimovic@msu.edu (*Corresponding author)

${ }^{2}$ Michigan State University, Department of Horticulture and Department of Forestry, 1066 Bogue Street, East Lansing, MI 48824-1325, USA.

${ }^{3}$ Michigan State University, Department of Entomology, 578 Wilson Road, East Lansing, MI 48824-1311, USA.

(C) 2016. This manuscript version is made available under the Elsevier user license http://www.elsevier.com/open-access/userlicense/1.0/ 


\section{Comparison of Drill- and Needle-based Tree Injection Technologies in Healing of Trunk Injection Ports on Apple Trees}

\section{ABSTRACT}

Excessive tree wounding is a common concern regarding the use of trunk injection technology for tree protection purposes in landscapes and urban greening. We investigated the rate of healing of injection ports (points) in apple trees by monitoring parameters such as port diameters, the size of bark cracking, and port depths. We compared drilled injection ports from 4.4 and $9.5 \mathrm{~mm}$ drill bits, with latter being sealed with plastic-silicone plug (Arborplug ${ }^{\circledR}$ ) or not, and the lenticular port from a double-edged blade. Depending on port size and type, port closure ranged from one to more than two years. Bark cracking around injection ports was more pronounced longitudinally. On the sealed $9.5 \mathrm{~mm}$ port, bark cracking was largely similar to all drilled ports. The depth of port wounds decreased faster on the port from the $4.4 \mathrm{~mm}$ drill bit and on lenticular injection port versus the unsealed port from the $9.5 \mathrm{~mm}$ drill bit. Plastic-silicone plugs, which simulate removed bark, slowed the healing of $9.5 \mathrm{~mm}$ drill port with callus and increased the port depths over time due to callus formation over the top of the plug. From fastest-healing to slowest-healing, on average the injection ports were: lenticular port from blade (70.8\%), the unsealed $9.5 \mathrm{~mm}$ drill port (44.4\%), $4.4 \mathrm{~mm}$ drill port (43.9\%), and $9.5 \mathrm{~mm}$ drill port sealed with plastic-silicone plug (20.4\%). 


\section{INTRODUCTION}

Trunk injection for delivery of plant protective compounds and nutrients provides targetprecise pest control and nutrient deficiency correction in landscape trees. Trunk injection as an in planta delivery method allows precise and confined compound delivery to trees (Ahmed et al., 2010; Guillot and Bory, 1997; VanWoerkom et al., 2014; Wilson, 1979; Wise et al., 2014). It is an environmentally safer alternative for pesticide application, which utilizes a tree's vascular system to translocate and distribute active compounds into the canopy (Percival and Boyle, 2005). Since injected compounds are enclosed within the tree, this method allows increased selectivity of exposure to pathogens and insect pests (Wise et al., 2014). Further, trunk injection is a superior delivery system because it enhances the activity of xylem mobile compounds such as oxytetracycline, which is used for fire blight control on crabapples and pears (Aćimović et al., 2015).

Tree injection developed primarily because ground- and air-spray applications were impractical due to large tree sizes, extensive drift-driven pesticide losses, reduced coverage, and proximity of urban areas (Düker et al., 2006; Guillot and Bory, 1997; Hillebrand et al., 1998).

Over the past two decades, this method has gained increased use due to the development and availability of injectable compound formulations and new injection devices (Doccola and Wild, 2012). These increase the efficiency of pesticides in pest control and the speed of the injection process (Dal Maso et al., 2014; Doccola et al., 2003; Doccola and Wild, 2012; Montecchio, 2013; Takai et al., 2003, 2004). Tree injection is steadily replacing seasonal spray treatments of trees and providing invaluable ecological service in landscapes and urban zones by reducing the exposure of applicators, environment, and wildlife to pesticide drift. Air-blast sprayers used in 
agricultural tree crops and pump sprayers used in landscape trees are rather inefficient in delivering pesticides to their target, with drift losses of spray solution into the environment of 4471\% (Perry, 1998; Reichard et al., 1979; Steiner, 1969; Zhu et al., 2006).

Despite widespread use of trunk injection technology in tree protection, trunk and bark wounding associated with the creation of injection points, i.e. injection ports, is an often-cited objection to the technique (Costonis, 1980; Doccola et al., 2011; Neely, 1988, 1979; Shigo, 1978; Smith and Lewis, 2005; Wasniewski et al., 1993a). An injection port is an opened point of access to trunk xylem. It allows direct delivery of a compound into the vascular tree tissues, which is then translocated into the canopy. Drill-based injection ports are most commonly used in landscape tree care and after injection can be left unsealed or are sealed with plastic-silicone plugs such as Arborplugs ${ }^{\circledR}$. An Arborplug allows delivery of an exact dose of choice into the tree by preventing leakage of injected solution from the port. Further, it prevents wood tissue drying and exposure of cambium to the injected liquid, thus allowing undisturbed port healing i.e. closure with callus produced from cambium. Finally, the exposed surface of the plastic-silicone plug simulates trunk bark removed by drilling and purposely compartmentalizes injection port according the basic principles of tree healing i.e. wound closure through compartmentalization (Shigo, 1984). A primary common concern of arborists is that wounding by injection ports could have a negative impact on tree health and longevity due to physical damage and/or formation of entry points for pathogens or insects. This concern is especially justified if injections are repeated for sustained pest control.

Even though there is limited research on the impact of injection ports on trees, seemingly less-injurious delivery systems for trunk injection or infusion of plant protective compounds have been developed (Düker et al., 2006; Düker and Kubiak, 2009a, 2009b; Doccola et al., 2003, 
2012; Shang et al., 2011a, 2011b; Düker and Kubiak, 2011a, 2011b; Montecchio, 2011, 2013).

Some of these systems were specifically designed to create lenticular injection ports which may lead to minimal injury of trunk tissues.

One of the important parameters for measuring the degree of harm from trunk injection wounds is the time needed for injection ports to heal. Only a handful of studies address or mention injection wound healing (Neely, 1979, 1988; Costonis, 1980; Wasniewski et al., 1993a; Percival and Boyle, 2005; Düker et al., 2006; Doccola et al., 2011; Smith and Lewis, 2005; Cooley et al., 1992; Shigo et al., 1977; Shigo and Marx, 1977). Overall, no research compared the levels of injury after creation of different types of injection ports and it is unclear whether tree wounding by injection leads to economically important damage to trees and impairment of tree longevity and functionality. To address this knowledge gap, using apple tree as a model, our objective was to compare the rate of injection port closure after the creation of different types and sizes of trunk injection ports. We chose apple tree due to thin and smooth bark, making measurements of wound closure rate easier.

\section{MATERIALS AND METHODS}

Creation of trunk injection ports. An experiment was conducted during 2012 and 2013 at Michigan State University's Plant Pathology Farm in East Lansing, Michigan (GPS: N42 ${ }^{\circ} 41^{\prime}$ 34.93", W84' 29' 31.657"). On 14 April 2012, 13-year-old 'Jonathan' apple trees, Malus domestica Borkh., were wounded with the four most common types of trunk injection ports: 1) drilled port $4.4 \mathrm{~mm}$ in diameter after using $4.4 \mathrm{~mm}$ wood drill bit, 2) drilled port $9.5 \mathrm{~mm}$ in diameter after using $9.5 \mathrm{~mm}$ wood drill bit, 3) drilled port $9.5 \mathrm{~mm}$ in diameter sealed with a 
plastic-silicone plug (Arborplug ${ }^{\circledR}$ no. 4, Arborjet Inc., Woburn, MA), and 4) lenticular port $1 \mathrm{~mm}$ wide, $28 \mathrm{~mm}$ high, after insertion of symmetrical double-edged blade $4 \mathrm{~mm}$ wide, $33 \mathrm{~mm}$ high, $50 \mathrm{~mm}$ long (Figure 1). A similar lenticular port is created with needle-insertion injection device with a flat-blade screwdriver-like needle, called Bite ${ }^{\circledR}$ (Montecchio, 2011). All injection ports were $25.4 \mathrm{~mm}$ deep and created by drilling into the trunk xylem with a cordless $1500 \mathrm{rpm}$ drill (DeWalt Industrial Tool Co., Baltimore, MD), or by insertion of a double-edge blade using hammer (Figure 1). The blade was inserted perpendicular to trunk axis so that it separated vertically-oriented wood fibers and opened a lenticular injection port in xylem (Figure 2D). To seal injection ports from $9.5 \mathrm{~mm}$ drill bit, we inserted plastic-silicone plugs $3 \mathrm{~mm}$ below the thin bark surface of apple tree and cambium. Thus, the orifice around the silicone septum for injection was in line with bark surface and cambium is exposed to air.

For each type of injection port, we used three replicate trees arranged in a completely randomized design (CRD) and each tree was injected four times with a given injection port type. Trunk ports were oriented according to cardinal directions and positioned $30 \mathrm{~cm}$ above the ground surface. Opposing ports, at $0^{\circ}$ and $180^{\circ}$, were offset vertically by approximately $5 \mathrm{~cm}$ of wood between them. In 2012, apple trees ranged from 7.1-10.2 cm in trunk diameter at $30 \mathrm{~cm}$ trunk height (average $8 \pm 0.36 \mathrm{~cm}$ ). In 2013, the same trees ranged from 7.8-11.4 cm in trunk diameter at $30 \mathrm{~cm}$ trunk height (average $8.8 \pm 0.45 \mathrm{~cm}$ ).

Measurement of injection port healing. All injection ports after creation on 14 April 2012 (Figures 2A-D) were measured on 20 July 2012 (Figures 2E-H), 14 April 2013, and 20 July 2013 (Figures 2I-L). We measured the following parameters for each port type using digital caliper: depth of injection port from the bark surface (Figures 2M-P), depth of injection port from the surface of plastic-silicone plug (Figure 2O), horizontal and vertical diameters of port opening 
surrounded by callus tissue (Figure 2R), and width and length of bark crack around the injection port (Figure 2R). If the entrance to port cavity was closed by callus from cambium, we measured port depth as the depth from surface of the old, raised periderm on the bark, around the injection port, to the new periderm from callus which is below the old periderm (Figure 2M). If the entrance to port cavity was closed by a plastic-silicone plug, we measured the port depth as the depth from the surface of old, raised periderm on the bark and the plug's surface (Figure 2O). For measuring injection port depth from surface of plastic-silicone plug, we inserted a needle through the silicone septum for injection, and measured this needle increment length.

Statistical analyses. Data were analyzed using MIXED procedure in SAS 9.3 (SAS Institute Inc., 2012). To normalize the residuals, we transformed data on horizontal diameter of port opening with callus with SQUARE ROOT (SQRT) function. For the data on length and width of bark crack around the injection port we used the COSINE (COS) transformation. We analyzed the effects of port type and time on horizontal and vertical diameters of port opening with callus, on the length and width of the bark crack, and on the injection port depth, by using CRD with repeated measures best adjusted with unstructured variance covariance structure. For drilled $9.5 \mathrm{~mm}$ port sealed with a plastic-silicone plug, we analyzed these effects by using CRD with repeated measures best adjusted with autoregressive covariance structure. We chose variance-covariance structures by lowering the AIC and BIC criterions. Tree was used as subject of repeated measurements through time.

When the effects of port type or time, or their interactions, were found to be statistically significant $(P<0.05)$, examination of interactions within main effects was performed, $F$-tests were carried out and pairwise or specific time or port type comparisons were conducted using $t$ test ( $\alpha=0.05)$ and using Tukey-Kramer test $(\alpha=0.05)$. 


\section{RESULTS}

The type of injection port, time, and their interaction, significantly affected the rate of port wound healing i.e. horizontal and vertical diameter of port opening with callus $(P<0.05$, Table 1, Supplement). Port type did not affect the width of bark crack, which changed over time (Table 1, Supplement). Port type affected the length of bark crack around the injection port, which did not change over time (Table 1, Supplement). Port depth changed depending on port type and time.

Diameter of port opening with callus. From 20 July 2012 onward, both horizontal and vertical diameters of callus tissue significantly declined on all port types, indicating on the ongoing healing of port wounds (Figures 2 and 3). Horizontal diameter declined i.e. closed for 5.6 and $12.3 \%$ faster than the vertical port diameter on the sealed $9.5 \mathrm{~mm}$ drill ports ( $23.2 \mathrm{vs}$. $17.6 \%$ ) and on $9.5 \mathrm{~mm}$ drill ports (50.5 vs. $38.2 \%$ ), respectively. In contrast, vertical diameter closed for 21.7 and $6.1 \%$ faster than the horizontal port diameter on $4.4 \mathrm{~mm}$ drill ports (54.7 vs. $33 \%$ ) and on blade ports (73.8 vs. 67.7\%), respectively (Figures 2 and 3). From fastest-healing to slowest-healing, on average the injection ports were: blade port (70.8\%), $9.5 \mathrm{~mm}$ drill port (44.4\%), $4.4 \mathrm{~mm}$ drill port (43.9\%), and the sealed $9.5 \mathrm{~mm}$ drill port (20.4\%).

None of the injection port wounds had completely healed by 20 July 2012. On 14 April 2013 (Figures 2 and 3), 11 out of 12 injection ports made by the $4.4 \mathrm{~mm}$ drill bit had healed (91.7\%), while 8 out of 12 wounds made by the blade had healed (66.7\%). On the same day, 5 out of 12 ports from $9.5 \mathrm{~mm}$ drill bit had healed (41.7\%), while none of the ports from $9.5 \mathrm{~mm}$ drill bit sealed with plastic-silicone plug had healed. By 20 July 2013 (Figures 2 and 3), only ports made by blade and $4.4 \mathrm{~mm}$ drill bit completely healed (100\%). At the end of the 
experiment, 9 out of 12 ports made by $9.5 \mathrm{~mm}$ drill bit had healed (75\%), while only one of the $9.5 \mathrm{~mm}$ drill ports sealed with the plug had healed (8.3\%) (Figures 2 and 3).

Bark crack size. Vertical cracking was evident around all port wounds. The length of bark cracks around the injection ports was much larger than their widths (Figure 4). The length of bark cracks around all drilled ports initially increased $129-432.9 \%$ faster than the widths (Figure 4). In contrast, the width of the blade port crack initially increased $124 \%$ faster than the length. From 20 July 2012 onward, width of bark crack increased significantly $(28.2-75.5 \%)$ for all port types except for the $9.5 \mathrm{~mm}$ sealed with the plug (27.3\%). In the same period, length of the bark crack did not change significantly for all port types $(7.1-20.1 \%)$. Examining the interaction of main effects showed that port types differed significantly only on 20 July 2012 (Figure 4), even though the difference between smallest and the largest bark cracks around ports were obvious. The appearance of bark cracking is shown in Figure 2. The largest width and length of bark cracking in sealed $9.5 \mathrm{~mm}$ drill port and blade port, respectively, can be attributed to the inserted plastic-silicone plug in drilled port and the largest length of blade port created by blade insertion.

Injection port depth. In all port types at the end of experiment, port depth from the bark surface was smaller when compared to the depth of plug-sealed port made by $9.5 \mathrm{~mm}$ drill bit (Figure 5). Until July 2012, port depth declined rapidly for the ports made by $4.4 \mathrm{~mm}$ drill bit (87\%) and blade (63\%), while for the port made by $9.5 \mathrm{~mm}$ drill bit the decline was delayed up until $2013(74.5 \%)$. On the plug-sealed port made by $9.5 \mathrm{~mm}$ drill bit, port depth primarily increased over time (275.5\%) (Figure 5). 


\section{DISCUSSION}

This study brings new insights on trunk injection wounding and rate of healing for four injection port types on apple trees. The results indicate that, depending on port type and size, the healing, i.e. port closure with callus, lasted for one to more than two years. Smaller drilled ports and the lenticular ports healed faster than the larger drilled ports, while sealing of the larger drilled ports with plastic-silicone plug was justified due to slow rate of closure. We demonstrate importance of multiple parameters in quantitative monitoring of injection port healing with emphasis on port opening, bark cracking, and port depth. This study will serve as a basis for any future and more detailed evaluations of the impact of injection ports on tree health, function, and longevity.

\section{Diameter of port opening with callus}

The frequency of closed injection ports and the diameters of callus tissue show the variable speed of wound healing depending on the port size and type. In general, the smaller the horizontal diameter of trunk injection port is, the faster the process of port healing, i.e. closure with callus tissue. This trend was similar for vertical diameter of callus tissue, except in the case of lenticular injection port, due to inherently larger port length from the blade. Further, the healing was faster on large diameter injection ports when these were unsealed with a plasticsilicone plug. Hence, the presence of a plastic-silicone plug, as a foreign object that seals the drilled port, significantly increases the time needed for complete port closure by callus. This, however, does not mean that port sealing with the plug should not be done. On the contrary, a plug mimics bark, creating a protective barrier to the compartment behind injection port. A plug 
is necessary for preventing entry of pathogens or insects during the healing process i.e. until complete wound closure with callus, which eventually occurs. With continued tree growth in diameter, sapwood growth rings form over the plug surface. Subsequently, both injection ports and plugs become part of the heartwood.

The trend of smaller ports healing more quickly than larger ones makes intuitive sense and follows with several previously published results with other tree species including Fraxinus americana L., Gleditsia triacanthos L. and Quercus palustris Münchh. As in the present study with apple trees, the level of wound closure with callus was correlated with cambium activity which enables radial trunk growth (Doccola et al., 2011; 1988, 1979; Percival and Boyle, 2005).

\section{Bark crack size}

The vertical reaction zone of the cambium appears to be more sensitive to cracking than horizontal reaction zone since the length of the bark crack around all injection port types initially increased faster and was much longer than the width. Cracking seems to be a direct response to interruption of vertical sap flow by injection port and localized cambium and phloem dehydration due to lack of water from xylem. To an extent, our observations on the sealed drilled ports and the blade ports align with bark cracking on Tsuga canadensis (L.) Carr., detected 1-2 growing seasons after injection with Viper Air/hydraulic micro-injection system ${ }^{\circledR}$ (Arborjet, Inc.,

Woburn, MA) and after use of Wedgle Direct-Inject ${ }^{\mathrm{TM}}$ System $^{\circledR}$ (ArborSystems LLC., Omaha, NE), respectively (Smith and Lewis, 2005).

\section{Port depth}


Callus forming from cambium covered the entrance to port cavities, resulting in a rapid decline in port depth in all port types, except in the two ports from $9.5 \mathrm{~mm}$ drill bit. The newly proliferating tissue "stretched" over to cover the port cavity and this led to port depth decline from the initial $25 \mathrm{~mm}$ (Figures 3 and 5). As anticipated and in accordance with wound compartmentalization as healing process in trees, the cavity in the xylem below the new cover of callus tissue remained empty in port made by $4.4 \mathrm{~mm}$ drill bit.

On the inside of the blade port cavity, we detected a callus tissue proliferating from ray parenchyma cells on the exposed xylem (Figure 6). This contributed to decline in port depth, besides the tendency of laterally separated wood fibers to retract into the previous position and re-seal or partially close the opened triangular cavity. This observation follows results with removed bark on cherry and other tree species after trunk girdling (Layne and Flore, 1991; Neely, 1979). Namely, when bark is removed so that cambium callus cannot "bridge over" i.e. cover the wound, the living cells of xylem parenchyma closest to the wound transform and start proliferating along the xylem rays. The new cells form extensive wound repair callus, which starts functioning as new bark with periderm, phloem, and cambium. It seems that this process occurs on apple trees but it remains unknown at which order of magnitude. We speculate that this callus formation from xylem parenchyma contributed to the increase of port depth in the sealed port from $9.5 \mathrm{~mm}$ drill bit. We did not conduct destructive autopsy of trees to confirm this since the main purpose of the study was to monitor healing of injection ports over time.

Increase in port depth on the sealed ports made by $9.5 \mathrm{~mm}$ drill bit occurred due to callus tissue growth over the surface of plastic-silicone plug. Since the plug has a fixed position in sapwood, the callus "stretching" over and above the plug rises as a protrusion, thus increasing the port depth. 
In July 2012, the port depth on the unsealed ports made by $9.5 \mathrm{~mm}$ drill bit was unchanged due to large port diameter. The large diameter of removed tissue in these ports prevents more rapid coverage with callus tissue, within one season. Hence, larger ports require more time to heal and therefore should be sealed with a plugs after creation. On the other hand, large diameter ports are widely used since they provide larger interface surface in opened xylem, allowing quicker infusion of injected liquid into the sapwood. This reduces labor time costs.

The most commonly observed side-effects of trunk injection of pesticides are tissue discoloration and dysfunctionality associated with phytotoxic effects of injected chemical, trunk splitting, weeping and fluxing of sap, cambium death or its distorted growth, and wood decay and rot due to infections by microorganisms (Shabi et al., 1974; Neely, 1979, 1988; Costonis, 1980, 1981; Santamour Jr, 1986; Perry et al., 1991; McGillivary et al., 1993; Wasniewski et al., 1993a; Shigo, 1978; Smith and Lewis, 2005; Shortle et al., 2010). During our two-year experiment no symptoms of fungal or bacterial infections in injection ports were detected.

The degree to which injection leads to tree function impairment is hypothesized to depend on variety of factors including tree species, pesticide formulation, and injection technology (Doccola et al., 2011; Doccola and Wild, 2012; Montecchio, 2013; Sachs et al., 1977; Santamour Jr, 1984). Some vigorous forest trees have the capacity to quickly heal the ports resulting in minimal disruption of function. Liriodendron tulipifera L. was able to effectively close drilled ports, $8 \mathrm{~mm}$ in diameter, after 16 months (Wasniewski et al., 1993a, 1993b). Physical wounding by injection ports on large diameter trunks of forest trees is often perceived as less severe than on the trees with smaller trunk diameter. Besides reported observations, only few in-depth reports quantify and qualify side effects of injection and the speed of port healing on trees. In Ulmus, injury due to drill-based injection can reflect in dead trunk bark and columns 
of discolored and compartmentalized xylem, extending 15 feet upwards and downwards and leading up to $40 \%$ of transport disruption (Perry et al., 1991). On apple trees there are reports of phyotoxicity on wood tissues or leaves (Guest et al., 1995; Long et al., 1989; Shabi et al., 1974). However, these studies rarely recognize that inadequate pesticide formulations and low rates of dilution with water could be the prime cause to the observed side effects (Doccola J. J., personal communication).

Due to tissue removal, drill-based injection technologies are perceived as damaging to the trunk. However, this technology allows port closure with the plug until callus develops, protects sapwood, and creates a temporarily active reservoir to which the solution is injected. Sometimes, drilled ports are left open after injection. The advantages of drill-based injection are the high level of xylem exposure to the injected liquid, fast solution uptake, uniform distribution of the injected compound in the tree, and low dependence on weather conditions and on developed leaf canopy to facilitate uptake if pressure is used to inject. Even though use of this technology is labor intensive, if it is used with formulations designed for injection, it secures relatively quick application, distribution, and efficient insect pest and disease control (Aćimović et al., 2016).

The main advantage of needle-based trunk injection technologies is the low extent of tree wounding by insertion of needle into the trunk, without removing trunk tissues (Montecchio, 2013, 2011). This allows faster port healing since vertically separated wood fibers partially retract after injection (Montecchio, 2013, 2011). The disadvantages of needle-based injection are low level of xylem exposure to the injected liquid, non-uniform compound distribution in the canopy, longer time required for application, and high dependence on developed leaf canopy and weather conditions (Aćimović et al., unpublished). 


\section{CONCLUSION}

Depending on injection port size and type, port healing occurs in 1-2 seasons. The smaller the width of trunk injection port, the faster is the process of port healing with callus. A protective plastic-silicone plug that closes the drilled port slowed the rate of port closure with callus. The length of bark cracking around all injection port types was larger than the width. The depth of injection ports declined faster when $4.4 \mathrm{~mm}$ drill bit or blade are used to inject, versus the $9.5 \mathrm{~mm}$ drill port. Sealing of $9.5 \mathrm{~mm}$ drill port with plastic-silicone plug increased the port depth due to callus formation on top and laterally around the plugs. In summary, from fastest- to slowest-healing the injection port types are: lenticular blade port, the unsealed $9.5 \mathrm{~mm}$ drill port, $4.4 \mathrm{~mm}$ drill port, and $9.5 \mathrm{~mm}$ drill port sealed with plastic-silicone plug. 


\section{FIGURES}

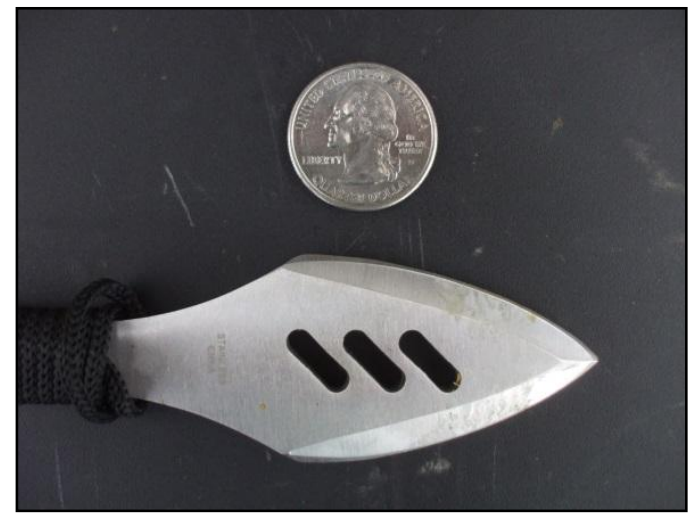

Figure 1. Double-edge blade $1 \times 28 \mathrm{~mm}$ used to create lenticular injection port by insertion into the trunk. Similar port is created by Bite ${ }^{\circledR}$ injection device with a flat screwdriver-like needle for infusion of trees (Montecchio, 2011). 


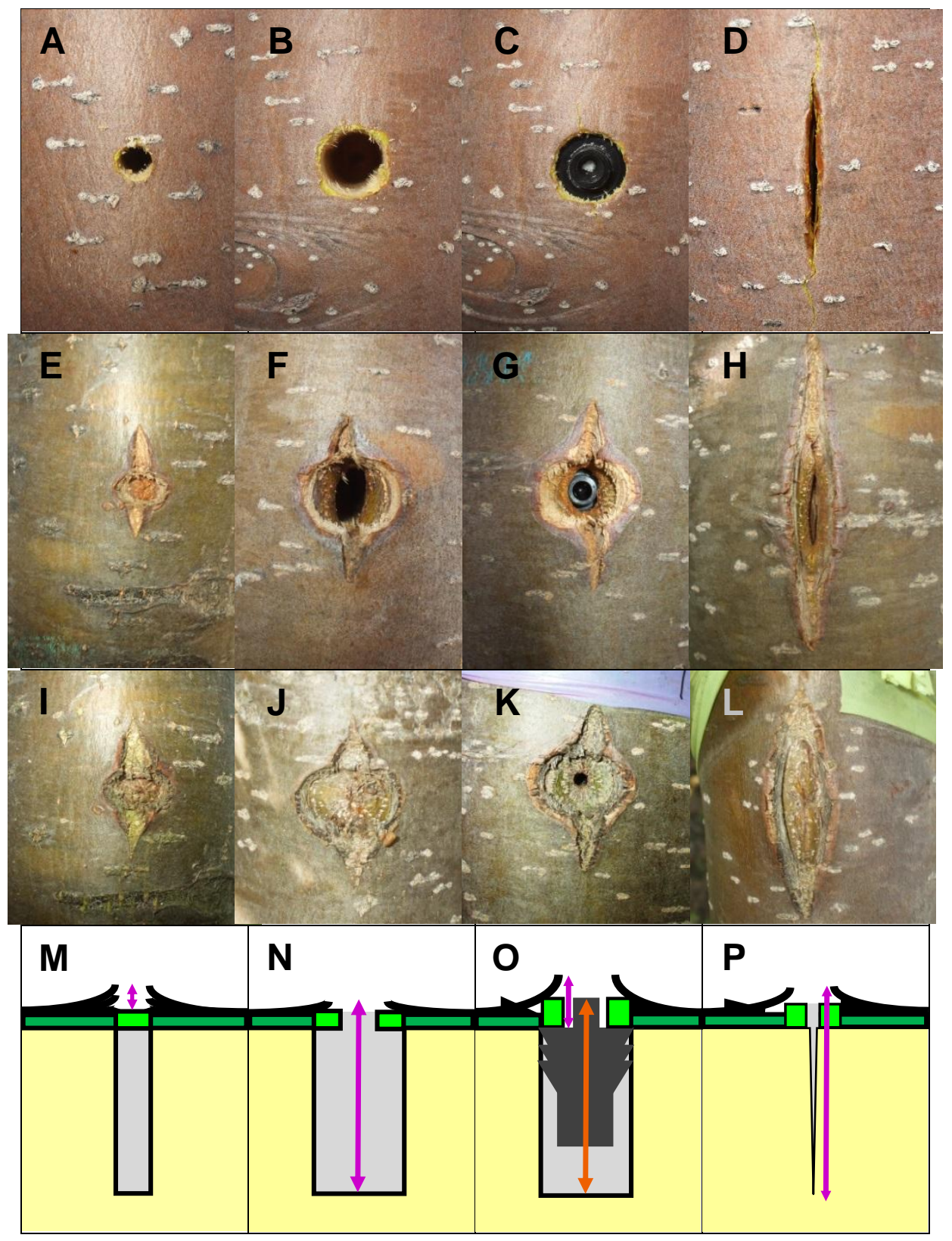




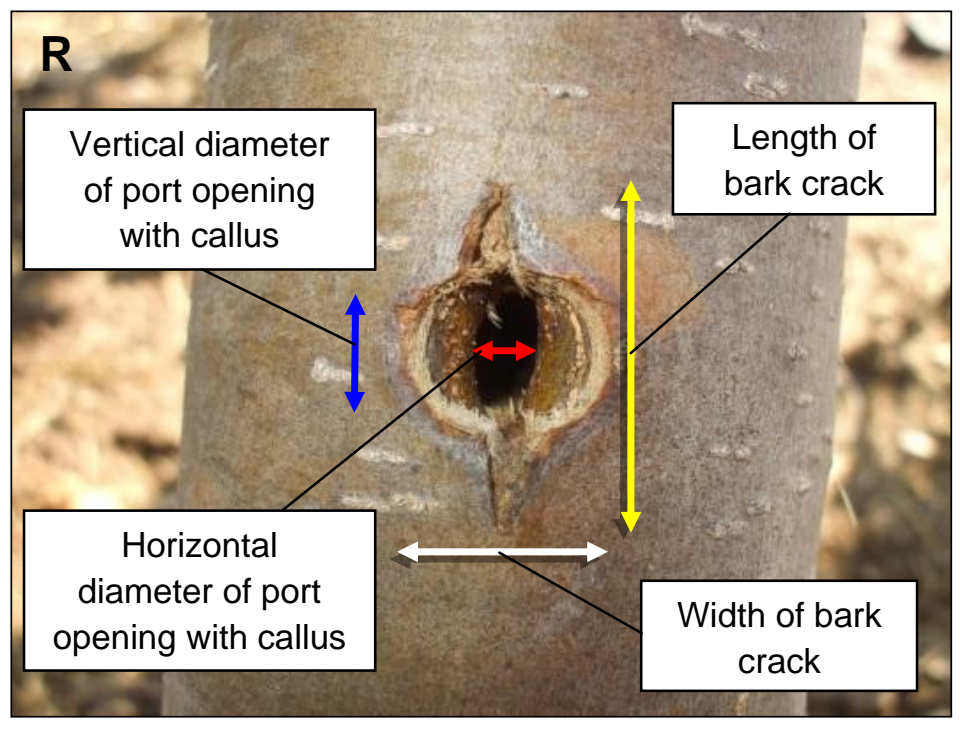

Figure 2. Trunk injection ports created on 14 April 2012 (A-D) and evaluated for healing on 20 July 2012 (E-H), 14 April 2103, and on 20 July 2013 (I-L). (A) 4.4 mm drill port, (B) $9.5 \mathrm{~mm}$ drill port, (C) $9.5 \mathrm{~mm}$ drill port sealed with plastic-silicone plug (Arborplug ${ }^{\circledR}$ no. 4, Arborjet Inc., Woburn, MA), and (D) lenticular port from double-edge blade (1 x 28 mm). (M-P) Port depth from bark surface (purple up down arrow) and port depth from surface of the plug (orange up down arrow). (R) Measured parameters of port healing. 


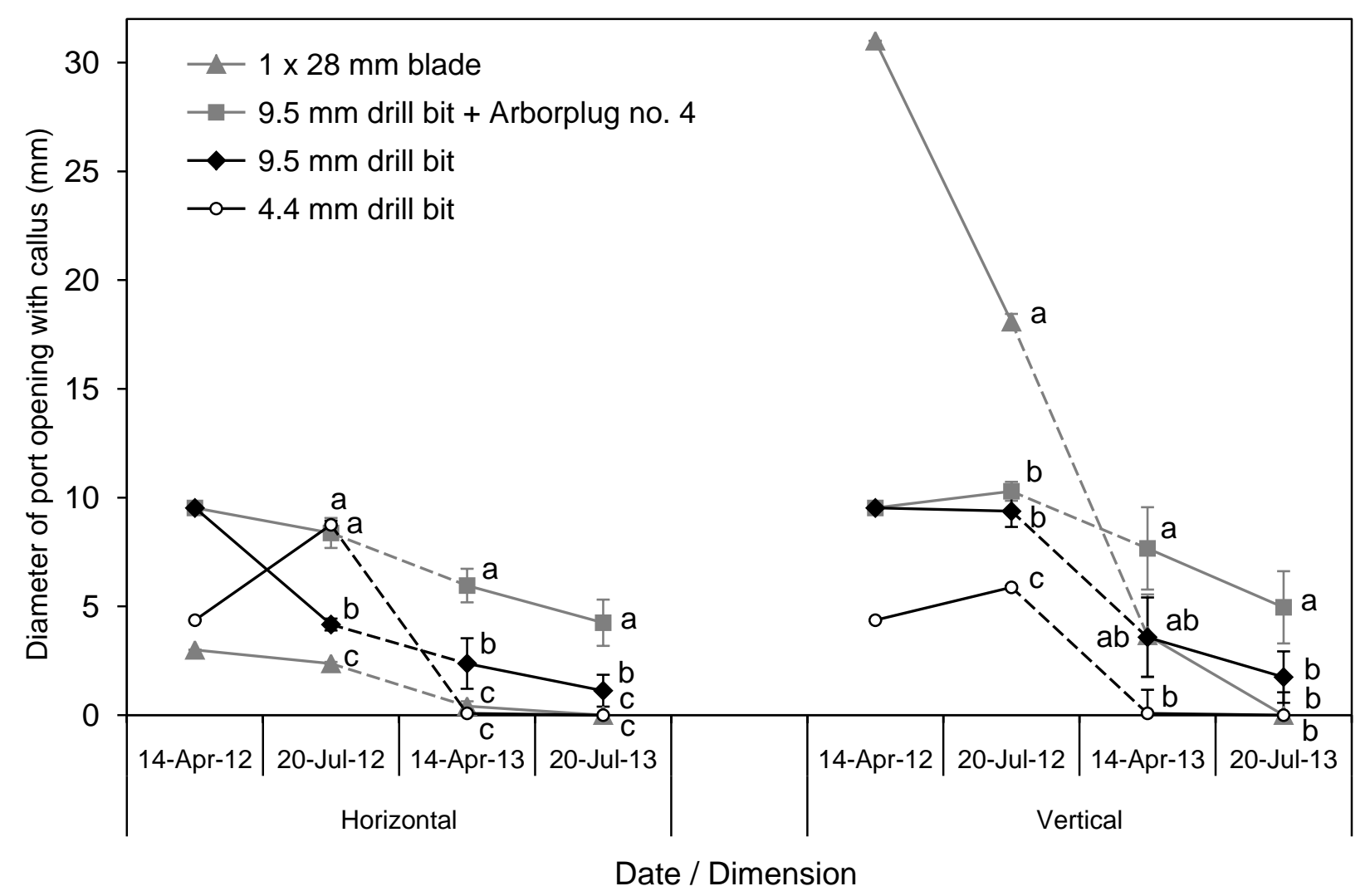

Figure 3. Change in diameter of port opening surrounded by callus tissue during two years after creation of different trunk injection ports. Means within one date followed by different letters are significantly different $(t$-test, $\alpha=0.05)$. Dashed line points are not on a continuous scale. Means consist of 3 replicate trees and 4 replicate wounds per each tree. Error bars represent standard error of the mean (SEM). 


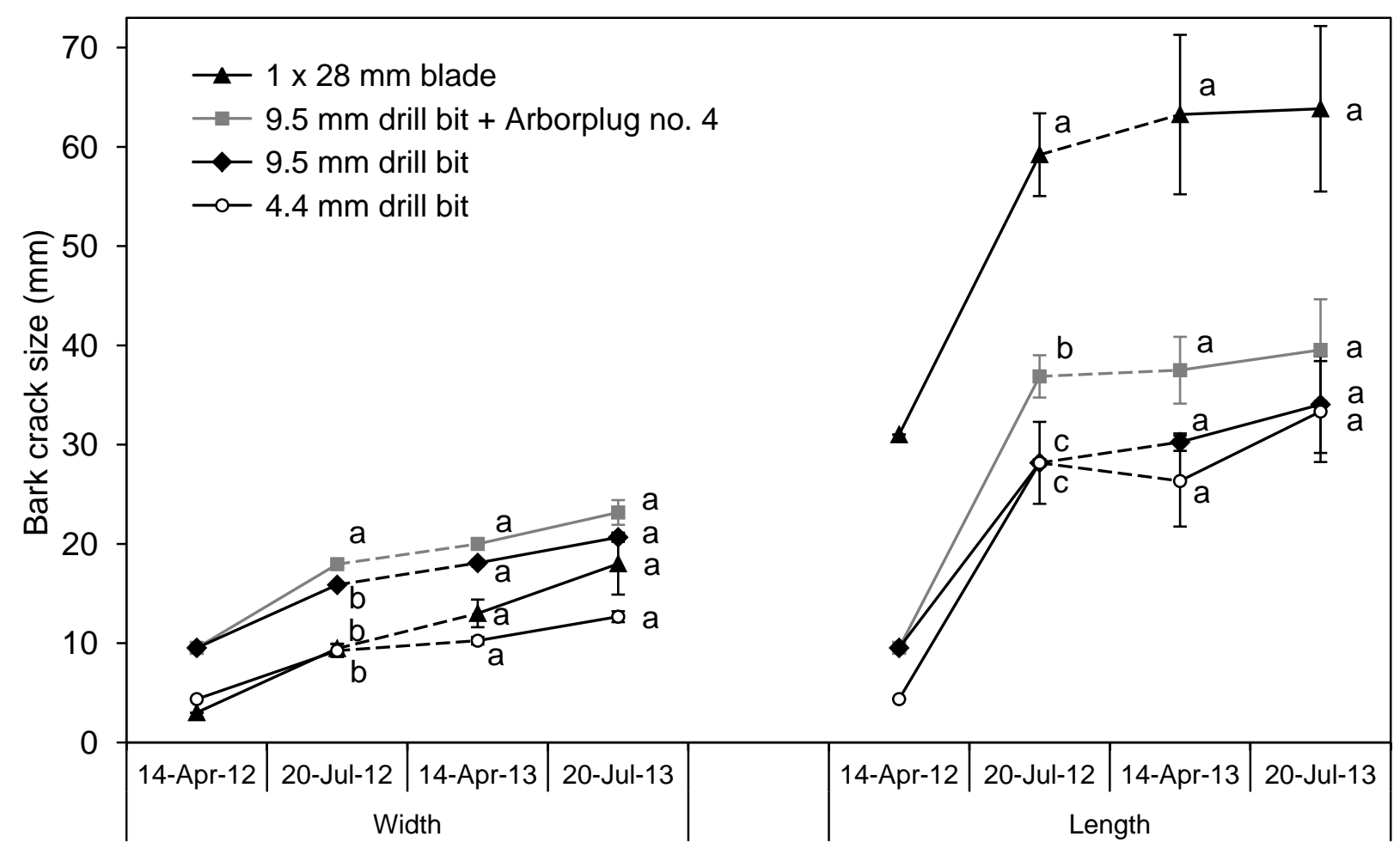

Date / Dimension

Figure 4. Change in bark crack size around different trunk injection ports two years after creation. Means within one date followed by different letters are significantly different $(\alpha=0.05)(t$-test for width; Tukey-Kramer test for length). Dashed line points are not on a continuous scale. Means consist of 3 replicate trees and 4 replicate wounds per each tree. Error bars represent standard error of the mean (SEM). 


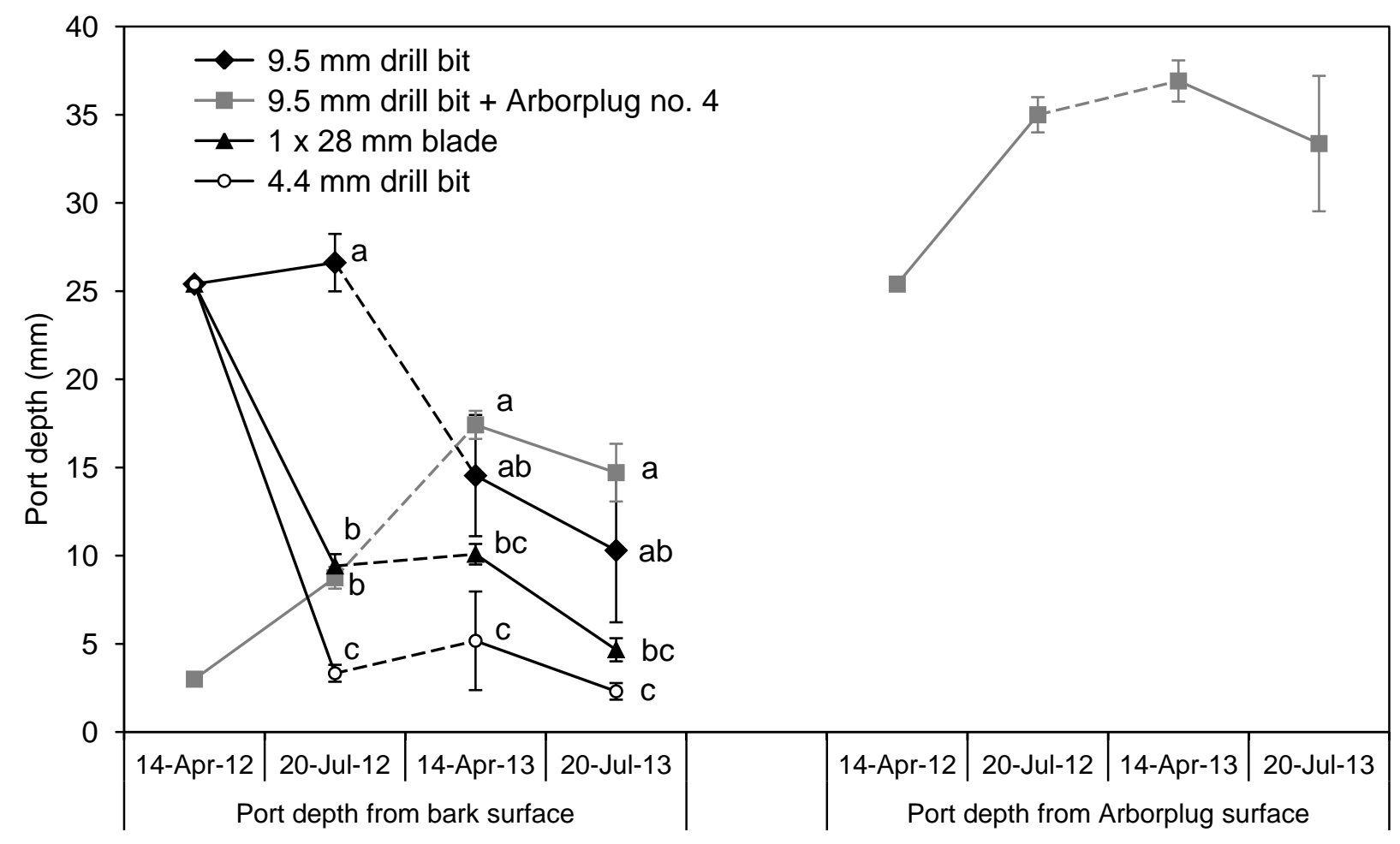

Date / dimension

Figure 5. Change in port depth around different trunk injection ports two years after creation ( $t$-test, $\alpha=0.05)$. Means within one date followed by different letters are significantly different $(t$-test, $\alpha=0.05)$. Dashed line points are not on a continuous scale. Means consist of 3 replicate trees and 4 replicate wounds per each tree. Error bars represent standard error of the mean (SEM). 


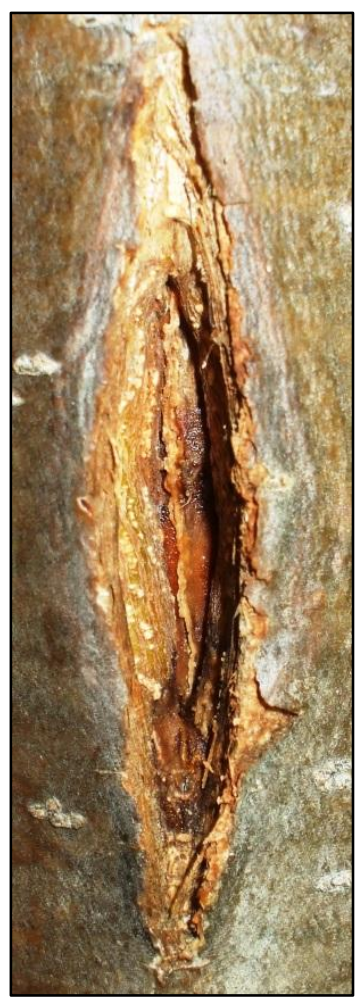

Figure 6. Formation of callus tissue from xylem parenchyma cells inside the port cavity on the lenticular trunk injection port from double-edge blade.

\section{ACKNOWLEDGEMENTS}

This work was funded by USDA-NIFA Pest Management Alternatives grant 201234381-20312 to JCW for the project "Trunk Injection: A Discriminating Delivery System for Tree Fruit IPM" and the resources of GWS at Michigan State University’s Plant Pathology Farm in Lansing, MI. The authors thank Dr. Joseph Doccola, director of Research and Development at Arborjet Inc. in Woburn, MA, for generously donating part of the equipment used in this research. The authors acknowledge graduate students Dana Aćimović and Daniel Hulbert, undergraduate student Christopher Meredith, and research technician Gail Ehret for help in collecting the data and for maintenance of experimental plot used in this project. 


\section{REFERENCES}

Aćimović, S.G., Zeng, Q., Mcghee, G.C., Sundin, G.W., Wise, J.C., 2015. Control of fire blight (Erwinia amylovora) on apple trees with trunk-injected plant resistance inducers and antibiotics and assessment of induction of pathogenesis-related protein genes. Front. Plant Sci. 6. doi:10.3389/fpls.2015.00016

Aćimović, S. G., VanWoerkom, A. H., Garavaglia, T., Vandervoort, C., Sundin, G. W., and Wise, J. C., 2016. Seasonal and cross-seasonal timing of fungicide trunk injections in apple trees to optimize management of apple scab. Plant Dis. doi: 10.1094/PDIS-09-151061-RE.

Ahmed, M.A., Abdelbagi, A.O., Elshafie, H.A., 2010. Trunk Injection with Neonictoniods Insecticides to Control the Green Pit Scale Insect (Palmapsis phoenicis Ramachandra Rao) (Homoptera: Asterolecaniidae) Infesting Date Palm in Northern Sudan, in: IV International Date Palm Conference, Acta Horticulturae (ISHS) 882. Abu Dhabi, United Arab Emirates, pp. 937-955.

Cooley, D.R., Tattar, T.A., Schieffer, J.T., 1992. Treatment of X-disease of Peaches Using Oxytetracycline Microinjection Capsules. HortScience 27, 235-237.

Costonis, A.C., 1981. Tree injection: Perspective macroinjection/micro-injection. J. Arboric. 7, 275-277.

Costonis, A.C., 1980. The wounding effects of Mauget and creative sales injections. J. Arboric. 6, 204-208.

Dal Maso, E., Cocking, J., Montecchio, L., 2014. Efficacy tests on commercial fungicides against ash dieback in vitro and by trunk injection. Urban For. Urban Green. http://dx.doi.org/10.1016/j.ufug.2014.07.005, 7. doi:10.1016/j.ufug.2014.07.005

Doccola, J.J., Hascher, W., Aiken, J.J., Wild, P.M., 2012. Treatment Strategies Using Imidacloprid in Hemlock Woolly Adelgid (Adelges tsugae Annand) Infested Eastern Hemlock (Tsuga canadensis Carrière) Trees. Arboric. Urban For. 38, 41-49.

Doccola, J.J., Smitley, D.R., Davis, T.W., Aiken, J.J., Wild, P.M., 2011. Tree Wound Responses Following Systemic Insecticide Trunk Injection Treatments in Green Ash (Fraxinus pennsylvanica Marsh.) as Determined by Destructive Autopsy. Arboric. Urban For. 37, 6.

Doccola, J.J., Wild, P.M., 2012. Tree Injection as an Alternative Method of Insecticide Application, in: Soloneski S, Larramendy M, Eds. Insecticides - Basic and Other Applications. InTech, Croatia, pp. 61-78.

Doccola, J.J., Wild, P.M., Ramasamy, I., Castillo, P., Taylor, C., 2003. Efficacy of arborjet viper microinjections in the management of hemlock woolly adelgid. J. Arboric. 29, 327-330.

Düker, A., Kubiak, R., 2011a. Stem injection of triazoles for the protection of "Vitis vinifera"L. ("Riesling”) against powdery mildew (“Uncinula necator"). Vitis J. Grapevine Res. 50, 73-79.

Düker, A., Kubiak, R., 2011b. Stem injection of prohexadione carboxylic acid to protect blossoms of apple trees from fire blight infection (Erwinia amylovora). J. Plant Dis. Prot. $118,156-160$.

Düker, A., Kubiak, R., 2009a. Stem application of metalaxyl for the protection of Vitis vinifera L. ('Riesling') leaves and grapes against downy mildew (Plasmopara viticola). Vitis 48, 43-48. 
Düker, A., Kubiak, R., 2009b. Long term stem-application in viticulture and the use of NeemAzal. Workshop Proceeding Biol. Control Plant Med. Vet. Pests Wetzlar Ger. 107.

Düker, A., Kubiak, R., Höfer, V., 2006. Stem application of plant protective agents in viticulture. Aachen: Shaker Verlag GmbH.

Guest, D.I., Pegg, K.G., Whiley, A.W., 1995. Control of Phytophthora Diseases of Tree Crops Using Trunk-Injected Phosphonates. Hortic. Rev. 299-330.

Guillot, O., Bory, G., 1997. Trunk insertion: a solution to urban trees chemical protection?, in: International Symposium on Urban Tree Health, Acta Horticulturae (ISHS) 496. Paris, France, pp. 137-146.

Hillebrand, W., Lorenz, D., Louis, F., 1998. Rebschutz. 11. Aufl. Fachverlag Fraund Mainz.

Layne, D.R., Flore, J.A., 1991. Response of Young, Fruiting Sour Cherry Trees to One-time Trunk Injury at Harvest Date. J. Am. Soc. Hortic. Sci. 116, 851-855.

Long, P.G., Miller, S.A., Davis, L.K., 1989. Duration of fungicidal effect following injection of apple trees with fosetyl-Al. J. Phytopathol. 124, 89-96. doi:10.1111/j.14390434.1989.tb04899.x

McGillivary, L.D., Wiest, S.C., Hensley, D.L., 1993. 631 (PS 3) Wound Closure Response to trunk Injection of the Growth Retardant Flurprimidol. HortScience 28, 541-541.

Montecchio, L., 2013. A Venturi Effect Can Help Cure Our Trees. J. Vis. Exp. doi:10.3791/51199

Montecchio, L., 2011. Bite - blade for infusion of trees, international patent by University of Padova, Italy.

Neely, D., 1988. Tree wound closure. J. Arboric. 14, 148-152.

Neely, D., 1979. Tree wounds and wound closure. J. Arboric. 5, 135-140.

Percival, G.C., Boyle, S., 2005. Evaluation of microcapsule trunk injections for the control of apple scab and powdery mildew. Ann. Appl. Biol. 147, 119-127. doi:10.1111/j.17447348.2005.00019.x

Perry, A.S., 1998. Insecticides in agriculture and environment: retrospects and prospects. Springer, New York City.

Perry, T.O., Santamour, F.S., Stipes, R.J., Shear, T., Shigo, A.L., 1991. Exploring alternatives to tree injection. J. Arboric. 17, 217-226.

Reichard, D.L., Fox, R.D., Brazee, R.D., Hall, F.R., 1979. Air velocities delivered by orchard air sprayers. Trans. ASAE Am. Soc. Agric. Eng. 22, 69-74.

Sachs, R., Nyland, G., Hackett, W., Coffelt, J., Debie, J., Giannini, G., 1977. Pressurized injection of aqueous solutions into tree trunks. Sci. Hortic. 6, 297-310.

Santamour Jr, F.S., 1986. Wound compartmentalization in tree cultivars: addendum. J. Arboric. USA 227-232.

Santamour Jr, F.S., 1984. Wound Compartmentalization in Cultivars of Acer, Gleditsia, and Other Genera. J Env. Hort 2, 123-125.

Shabi, E., Pinkas, Y., Solel, Z., 1974. Distribution of Benzimidazole Fungicides Following Pressure Injection of Pear Trees at Several Growth Stages. Phytopathology 64, 963-966.

Shang, Q., Liao, K., Liu, H., Zhao, B., 2011a. Study on structure of needle head and seal mechanism of tree trunk injection, in: 2011 International Conference on Transportation, Mechanical, and Electrical Engineering (TMEE). Presented at the 2011 International Conference on Transportation, Mechanical, and Electrical Engineering (TMEE), pp. 813 -816. doi:10.1109/TMEE.2011.6199326 
Shang, Q., Tan, Q., Zhang, Y., Zhao, B., 2011b. The study of motorized trunk treatment with advance and retreat injection needle and its clamping structure, in: Mechanic Automation and Control Engineering (MACE), 2011 Second International Conference on. IEEE, pp. 4616-4619.

Shigo, A.L., 1984. Compartmentalization: a conceptual framework for understanding how trees grow and defend themselves. Annu. Rev. Phytopathol. 22, 189-214.

Shigo, A.L., 1978. How to minimize the injury caused by injection wounds in trees, in: Proceedings of Symposium on Systemic Chemical Treatments in Tree Culture, October 9-11, 1978, Held at Michigan State University, Kellogg Center for Continuing Education, East Lansing, Michigan.

Shigo, A.L., Marx, H.G., 1977. Compartmentalization of decay in trees. Forest Service, Dept. of Agriculture.

Shigo, A., Money, W., Dodds, D., 1977. Some internal effects of Mauget tree injections. J. Arboric. 3, 213-220.

Shortle, W.C., Dudzik, K.R., Smith, K.T., 2010. Development of wood decay in wound-initiated discolored wood of eastern red cedar. Holzforschung 64, 529-536.

Smith, K.T., Lewis, P.A., 2005. Potential Concerns for Tree Wound Response from Stem Injection, in: Proceedings of the Third Hemlock Woolly Adelgid conference;2005 February 1-3; Asheville, NC. FHTET-2005-01. U.S. Department of Agriculture, Forest Service, Forest Health Technology Enterprise Team. pp. 173-178.

Steiner, P.W., 1969. The distribution of spray material between target and non-target areas of a mature apple orchard by airblast equipment. M.S. thesis, Cornell University. Cornell University.

Takai, K., Suzuki, T., Kawazu, K., 2004. Distribution and persistence of emamectin benzoate at efficacious concentrations in pine tissues after injection of a liquid formulation. Pest Manag. Sci. 60, 42-48. doi:10.1002/ps.777

Takai, K., Suzuki, T., Kawazu, K., 2003. Development and preventative effect against pine wilt disease of a novel liquid formulation of emamectin benzoate. Pest Manag. Sci. 59, 365370. doi:10.1002/ps.651

VanWoerkom, A.H., Aćimović, S.G., Sundin, G.W., Cregg, B.M., Mota-Sanchez, D., Vandervoort, C., Wise, J.C., 2014. Trunk injection: An alternative technique for pesticide delivery in apples. Crop Prot. 65, 173-185. doi:10.1016/j.cropro.2014.05.017

Wasniewski, T.A., Chaney, W.R., Holt, H.A., 1993a. Hole angle for trunk injection of tree growth regulators and its affect on weeping, wound closure and wood discoloration. J. Arboric. 19, 131-131.

Wasniewski, T.A., Chaney, W.R., Holt, H.A., Senf, J.F., 1993b. Strength properties of wood related to trunk injection of tree growth regulators. J. Arboric. 19, 220-220.

Wilson, C.L., 1979. Injection and infusion of trees, in: Proceedings of the Symposium on Systemic Chemical Treatments in Tree Culture. Michigan State University, East Lansing, MI, USA, pp. 1-6.

Wise, J.C., VanWoerkom, A.H., Aćimović, S.G., Sundin, G.W., Cregg, B.M., 2014. Trunk Injection: A Discriminating Delivering System for Horticulture Crop IPM. J. Entomol. Ornithol. Herpetol. 3, 126. doi:10.4172/2161-0983.1000126

Zhu, H., Derksen, R.C., Guler, H., Krause, C.R., Ozkan, H.E., 2006. Foliar Deposition And OffTarget Loss With Different Spray Techniques In Nursery Applications. Trans. ASAE Am. Soc. Agric. Eng. 49, 325-334. 
